\title{
Money Politics and Vote Buying in Nigeria: The Bane of Good Governance
}

\author{
Ovwasa O. Lucky Ph.D (Associate Professor) \\ Head, Department of Political Science, Faculty of Arts and Social Sciences, \\ Federal University, Lokoja, Kogi State, Nigeria
}

\section{Doi:10.5901/mjss.2014.v5n7p99}

\begin{abstract}
Obviously in Nigeria, Money Politics and Vote Buying have taken the centre stage in our political activities. This is because parties and candidates have shown by their conduct during political campaigns, that good party manifestoes and integrity of candidates jostling for public offices are no longer sufficient to guarantee electoral success. Thus, the resort to Vote-buying. On the other hand, the electorates too have obviously demonstrated cynical electoral behavior by the readiness to sell their votes to the highest bidder. This uncharitable behavior or practice constitutes a blemish on public policy and the electoral process. In fact, it portends dangers to the democratic process of electing officers and in turn prevents good Governance. While it may be difficult to eliminate the phenomenon of Money Politics and Vote-buying its negative consequences on the Nigerian Polity can be minimized by the various recommendations that are made at the end of this paper.
\end{abstract}

\section{Introduction}

Many Scholars such as (Davies, 2005, Walecki 2006, Scaffer 2005, Schedler 2005, Ojo 2006) have written on money politics and vote buying in Nigerian politics because of the devastating impact of the phenomenon on the body politics. The Nigerian state often experiences governmental instability in the forms of bad policy options and implementation. The basic necessities of life such as electricity supply, water supply, employment and quality education are lacking in the Nigerian society.

Democracy which is adjudged to be the best form of government all over the world is also being constantly assaulted in Nigeria due to the phenomenon of money politics and vote buying. Although, Nigeria enthroned democratic governance in the fourth republic on May 29th, 1999, the dividends of democracy to the people are very scanty and far apart. This is because the concept and practice of democracy appears to be at variance in Nigeria. Actually money politics and vote buying have vitiated the good qualities of democracy in the country. In fact, the destructive power of money politics has been fingered as one of the factors that undermine good governance in Nigeria.

The role that money and vote buying play in Nigeria politics today have earned them a dominant position in the election of officers into position of authority where they can authoritatively decide who gets what, when and how. Money seems to have taken the center stage in the political process in most countries and in Nigerian politics, it is, sadly, now playing an increasing critical role to such an extent that the word, 'money politics' with a pejorative connotation, have crept into the country's political lexicon", (Davies: 2006:5). The problem with this situation is that the electoral process is often compromised resulting in elections not being free and fair.

It is pertinent to observe that it is not in any way being suggested that the use of money by political parties or any person or group of persons in politics has inherent corruptive influence. The truth is that money is needed for sundry services and logistics such as mobilization for political campaigns and rallies, printing of posters and manifestoes, production of party emblems and other symbols etc. The only worry, however, is the noticeable corrupting influence of money and vote-buying, and their negative impact on good governance in Nigeria.

\section{Conceptual Clarification}

Money politics can be defined as the phenomenon in the Nigeria electoral process whereby contenders for elective positions used money or money is used on their behalf as an inducement to sway their support which is not based on persuading the electorates to vote according to their wish and conviction but on the force of money that has changed hands. Related to this, is outright vote-buying. Vote-buying in its literal sense, is a simple economic exchange. According to (Fredrick Charles and Andrea's Schedler 2005) candidates 'buy' and citizens/electorates 'sell "vote, as they buy and sell apples, shoes or television sets". The act of vote-buying by this view is a contract or perhaps an auction in which 
voters sell their votes to the highest bidder. Parties and candidates buy vote by offering particularistic material benefits to voters. Candidates may generally aspire to purchase political support at the ballot box in accordance with the idea of market exchange. For analytical purpose, it is necessary to point out, that the commercial aspirations of vote buyers' may run into two barriers, namely; objective and inter-subjective barriers. On the objective side, seller compliance is uncertain, as vote buying is an illicit business and as such does not take place within a "normal' market protected by social and legal norms. On the inter-subjective side, empirical accounts of participants' perspective revealed that those electoral practices we describe as "Vote-Buying" may carry different meaning in different cultural context.

This is so because, in both historical and comparative perspective, vote-buying as a phenomenon is neither system specific nor space bound (Ojo: 2006:5). In all systems, be it developed or developing, medieval or contemporary, vote buying occurs in all regions and climes. The only difference is that it differs in magnitude and manifestation from one polity to the other. Regions or locales where episodic, electorate-related gift giving or favour rendering is common include Benin, Taiwan, Japan Northern Portugal and the slums of Metro Minica (Ojo iid). Moral debts can be created in more efficacious or obliged manner as well. As one Felipino succinctly observed:

Once a candidate has sworn in a registered voter as a partisan poll watcher, he or she can expect that the latter will vote for him or her. Our Felipino trait of Utanga n loob* (debt of gratitude) is evident in this case. Once a person has granted us something, a favour, we would do everything to pay that favour back to him or her, sometimes even at the expense of ourselves. We tend to view persons who did us some good things as beneficiaries who can please them by doing the same for them (Bara 2007).

This practice which rests upon pay offs that are not directly and explicitly tied to reciprocity in the polling booth, is sometimes referred to as indirect vote-buying. This practice was well known in $19^{\text {th }}$ century England and early $20^{\text {th }}$ century. France, and is common today in the Philippines and in the squatter settlements of Quito, Ecuador. In Taiwan, vote brokers typically approach relatives, friends and neighbours. A similar tactics is also employed in Thailand. For example, in the 1992 election in Thailand campaign workers for one candidate sought in each village "to recruit the person best placed to deliver support, generally someone with significant social status in the village. Other qualifications include being respectable, well known, a local leader (either official or unofficial), the candidate's relative or close friends, or some other characteristics that would make people honour their vote promises (Callahan:2000).

The use of money to buy votes does not even stop at election time. It is a common practice in Nigeria as it is in many other countries, for numerous private interest groups and political action committees which seek policy goals and legislations to serve their narrow private needs to continue to use all the means at their disposal including money, to solidify or expand their influence on the elected officials (Wright: 1985). It is observed that the relative ease with which the elected officials show their gratitude by endorsing the legislative and policy proposals of campaign contributors seems to support the hypothesis that there is a correlation between special donations to political parties and candidates and legislative votes.

Consequently, according to Sohner (1973:190) "money has, in fact, been made to become the mothers' milk of politics, which the political gladiators must drink to remain in business".

Good governance which suffers because of the phenomenon of money politics and vote-buying can be defined as all the governmental and institutional arrangements in a polity which are operated on the basis of strict compliance with the tenets and practices of democracy. All stakeholders must uphold the tenets of access to quality education, economic empowerment, effective health-care delivery system, rule of law and other necessary social amenities. All seem to agree that democracy is the best and the most civilized method of governance known to man. Consequently it has attracted much attention from both scholars and statesmen. Regrettably however, there is no known definition of the concept that is universally acceptable. This is, perhaps, due to its atavistic nature.

The liberal democratic perspective, defines democracy as a method of government which allows citizens of a state the freedom to choose their representatives through elections at regular intervals. This perspective of democracy with its periodic elections notwithstanding, has been criticized by scholars because of the limitations, it places on political participation by the citizens. It is argued that it is not representative enough because of its emphasis on material conditions before citizens can adequately participate in the democratic exchange. As Saliu and Lipade pointed out:

A great chunk of the population is excluded from the mainstream political process due to institutionalized social and economic constraints. For instance, the emphasis on certificated education and acquisition of properties obviously put the elite in more vantage position to dominate the vast majority (Saliu and Lipade: 2008).

Whatever, the merits of this argument there are certain minimum tenets of democracy that must be present in any polity for good governance to thrive. These procedural minimal conditions that must be present for modern political democracy to exist are according to Dahl seven in number. For him, the following seven conditions are most suitable for modern democracy to exist. 
i. Control over governmental decisions about policy is constitutionally vested in elected officials.

ii. Elected officials are chosen in frequent and fairly conducted elections in which coercion is comparatively uncommon.

iii. Particularly, all adults have the right to vote in the election of officials.

iv. Citizens have the right to express themselves on political matters without the danger of severe punishment.

v. Citizens have the right to seek out alternative sources of information that are protected by law.

vi. Citizens have a right to form relatively independent political parties and interest groups. (Dahl, 1971:39).

In Nigeria today, and in most other African countries, the citizens are now more interested in the delivery aspects of democracy as a system of government. This is because more citizens now increasingly, look forward to the dividends of democracy to transform their present poor existence to a situation in which all their material wants would be satisfied. This transformation can only be achieved through the operation of good governance based on the minimal seven conditions mentioned above. But unfortunately, this aspiration of the majority conflicts and contrast very sharply with the perception of the propertied politicians who, not surprising, but conveniently, choose to see democracy as essentially a mechanism for more capital accumulation and consolidation.

\section{An Overview of Money Politics and Vote-Buying in Post Colonial Nigeria}

The phenomenon of money politics and vote-buying only became prominent in post independent Nigeria. Even then, their influence was very minimal in the first republic between 1960 - 1966. During the first republic, appeals to ethnic and religious sentiments were the most important weapons the political leaders and tribal heroes deployed to ensure electoral victories. This was possible because the strength and popularity of the major political parties and their allies were essentially enhanced by the primordial ties they had with the people in their regions. The parliamentary system that was being practiced then, also made it possible for the political parties to exercise considerable control over the candidates to be fielded for elections. As Dudley correctly observed:

Candidates in the elections were less important as the parties took the centre stage, appealed to ethnicity played alliance politics and used highly emotive terms which in most cases invited people to violence. Most of the election expenses were borne by the parties from the funds they were able to raise (Dudley 1982:68)

It should be noted, however, that although politicians were known to distribute T-Shirts, Caps and badges with party emblems, some food stuff and sundry items, to voters at political rallies, there was no huge spending by individual candidates to win elections as obtains currently in the political activities of candidates.

Money politics and vote-buying escalated to greater dimensions during the second republic which started in 1979.

It was perhaps, encouraged by some wealthy Nigerians who made their money during the Nigerian civil war between 1967 - 1970, by probably supplying arms and ammunitions to both parties to the war and those who were government contractors, reconstructing projects, after the destructive civil war. And, as soon as the military signaled the commencement of competitive politics, these people ventured into politics or sponsored candidates for elective office. Davies in a recent work summarizes the situation as follows:

There was so much display of affluence and use of money by the wealthy contractors and the mercantile class that those who emerged victorious in the conventions and the primaries of some of the political parties, notably the National Party of Nigeria (NPN), the Nigerian People's Party (NPP) and the Unity Party of Nigeria (UPN) belonged to the businessmanagerial group (Davies, 2006).

The situation was even worse in 1993 as the act of money politics and vote-buying took very firm roots in the political activities of contestants. This was because the political campaigns for the conduct of the 1993 election demonstrated excessive use of money during the party primaries and the presidential elections, despite the fact that the elections were conducted under the watchful eyes of the military. The rich had actually hijacked the two political parties decreed into existence by the military, namely the National Republican Convention (NRC) and the Social Democratic Party (SDP). At the primaries for example, the use of money to win party nomination was pervasive while complaints of bribery trailed the results. As one of the contestant who lost out claimed. "Money was paid to party functionaries, who were demanding and negotiating the amount of money to be given to them for payment to win offices and others, and for how votes will be allocated to aspirants" (Nwosu, 1996:78).

Interestingly enough, the noticeable excessive use of money during the 1993 presidential election was ostensibly adduced by president Babangida to annul the election. In annulling the 1993 election, he declared:

There were authenticated reports of election malpractice against agents, officials of the NEC and voters... there were proof of manipulation, offers and acceptance of money and other forms of bribery. The amount of money spent by the presidential candidates was over 2.1 million naira (Ojo, 2000). 
Similarly, money politics and vote-buying reached their pinnacles in the elections that ushered in the current democratically elected government in 1999 and the civilian-civilian transition elections of 2003, 2007 and 2011, as one political scientist once observed, "if the use of money in the 1999 elections was open and shameless that of 2003 was outrageously indecent (Suberu, 2001). This seemed to have ironically pricked the conscience of former President Obasanjo, who was a beneficiary of the sordid act in the two elections to admit though, belatedly that:

With so much resources being deployed to capture elective offices, it is not difficult to see the correlation between politics and the potential for high level corruption. The greatest losers are the ordinary people, those voters whose faith and investment in the system are hijacked and subverted because money, not their will, is made the determining factor in elections. Can we not move from politics of money materialism to politics of ideas, issues and development (Obasanjo, 2005).

Money politics and vote-buying assumed a frightening and consummative dimension in the 2007 elections. This is because the use of money to buy conscience appeared to have been extended to the judiciary. It will be recalled that the Governorship Candidate of the Action Congress (AC) now Action Congress of Nigeria (ACN) Engineer Rauf Aregbesola had dragged the Osun State Governor Olagunsoye Oyinlola, of the People's Democratic Party (PDP) to the Osun State First Elections Petitions Tribunal to challenge his election as the Governor of Osun State for the second term.

The News Magazine of $6^{\text {th }}$ July 2008, made damaging allegations against the Tribunal members and the counsel to Governor Oyinlola. The news magazine reported how two judges of the Osun State First Elections Tribunal, namely, Thomas Naron (Chairman) and J.F. Ekanem were alleged to have "Slipped into Cesspool of scandal" by their very regular telephone calls and text messages to Kunle Kalejaiye (SAN) (The News Magazine July 2008) the lead Counsel to Governor Oyinlola. Although these were mere allegations but they were weighty enough to cast the Judiciary in bad light since it is unethical for the judges of the tribunal to have private discussion regarding the case without the presence or the representative of the petitioner. As widely expected and perhaps, because of this "Unholy Marriage" between the tribunal judges and the lead Counsel to Oyinlola, the verdict was given in favour of Oyinlola. In rejecting the judgment, the ACN said "the discredited election petition tribunal in Osegbo delivered its obnoxious judgment without any atom of moral scruple or an eye for Justice (Fayeniwo:2008). It took another two years of legal battle before this ugly situation was reverted. This is because, the Appeal Court sitting at Ibadan set aside the First Elections Petitions Tribunal Judgment and decided the case in favour of ACN candidate Rauf Aregbesola on the $26^{\text {th }}$ of November, 2010, and directed that he be sworn in as Osun State Governor on the $27^{\text {th }}$ of November, 2010. This was why there was no governorship election in Osun State on April 26 2011.

The fact is that the use of money or any other inducement for that matter, to perverse justice creates problems for good governance. Commenting on the high use of money in Nigerian politics the Guardian of May 31st, 2008 has this to say:

In a country where money politics is very high, the opposition candidates are in disadvantaged position before the polls. The fact that a politician is out of power, having lost patronage easily loses followership makes matter worst. And because most politicians of today cannot look beyond their nose, they soon become orphaned (The Guardian:2008).

It is obvious from the analysis so far, that the use of money in Nigerian politics is unbridled and the polity is characterized by this reckless use of money to buy votes and even conscience. The politicians are ready to channel their financial and material resources to secure electoral victory at the polls or at the tribunals. What then are the factors that are responsible for this situation in Nigeria where money politics and vote-buying have taken the centre stage in our political lives. The discussion of the predisposing factors of money politics and vote-buying forms the next stage of this article.

\section{Why Money Politics and Vote-Buying?}

So many reasons can be adduced as being responsible for the incidence of money politics and vote-buying in Nigeria. Some of these factors include ignorance, on the part of the electorate, apathy, and poverty as well as, deceit by the politicians. There is also attitudinal problem on the part of the people involved in both buying and selling. Our attitude towards politics is not right, because most politicians view it as a call to investment from which huge profit is expected and not as call to serve humanity. The electorates on their part see politics especially during election, as an opportunity to sell their votes to represent their own share of the national cake since they do not have access to where the national cake is being shared. Davies, in a recent perspective work had identified seven predisposing factors which captured almost 
completely the reason for the very high incidence of money politics and vote-buying in Nigeria. The factors as identified by Davies (2006) are reproduced below as follows:

a. The inability of many political parties and the contestants to put in place comprehensive and comprehensible manifestoes for scrutiny by the voters. Instead of clear-cut manifestoes that would enable the electorate to make a rational political choice, meaningless slogans, demagogic and rabblerousing speeches are made. Such speeches either overestimate or underestimate the political perception of the voters, but are rarely educative and convincing. Many voters seem to be unimpressed by all the tricks the Parties and the candidates employ, hence the need to bribe them for their votes.

b. Political cynicism on the part of the voters who believe that political office holder are incurably corrupt, selfseeking and incompetent, that politics is a dirty and dishonorable enterprise, that the whole political process is a fraud and a betrayal of the public trust. This cynical view of politics is further accentuated by unfulfilled promises made by winners of past elections. Thus, asking for a pay-off, another way by which the people receive their own share of the national cake. On the other hand, the candidates who gave money to voters probably believe that they are investing against electoral failure.

c. Focusing on personalities rather than on issues. By the mode of their campaign, most candidates draw the attention of the electorate away from the political parties to themselves. The consequence of this is that the political parties and their message become less important to the electorate. The candidates then take the centre stage and would therefore need to spend more money than their parties could afford in order to mobilize support for themselves.

d. The peoples' perception greatly reinforced by obscene display of opulence by public office holders and ostentatious living of many politicians that every elected or appointed public officer is amassing wealth from the public treasury. This seems to have strengthened the resolve of many voters to sell their votes to the highest bidder.

e. The penchant of politicians to strive to win elections, even at the party primary level, at all cost, makes desperate contestants to engage in all sort of malpractices including offering financial and material inducements to voters. Working on the poverty of the people, Nigerian politicians have been known to distribute food stuff and other consumable materials to voters shortly before the elections and sometime on Election Day, contrary to the provision of the extant electoral law that prohibits such practice. Instances abound too, when candidates threw some money into the air during campaign rallies, making people to scramble for it and getting injured in the process.

f. The noticeable weakness in a party whip, characteristics of party politics in presidential system, when elected members exercise considerable degree of freedom when voting on legislative proposals. Such freedom makes the legislators to be more susceptible to receive gratifications from the private interest groups. The interest groups employ what Shank calls "legalized bribery". They make large donations to some spurious private or community programmes in which the target legislators are interested, and give expensive gifts to the legislators or sponsor their overseas travel etc. all in the name of public relations to secure the votes of the legislators in the legislature.

g. The absence of any legislation that puts any ceiling on financial contributions to political parties and candidates by groups or individual (Davies, 2006).

But we must quickly add that the Nigerian constitution is not completely silent on party finances, but its provisions in respect of the finances of political parties relate only to their source of funds and other assets. For example, section 225(3) of the 1999 constitution merely prohibits any political party to (a) retain any funds or assets remitted or sent to it from outside Nigeria. The requirement that political parties prepare and submit audited account to the electoral body is only intended to ensure transparency and accountability. No law exists as of now, that puts any limit to the amount candidates can spend in elections while the National Assembly is yet to issue guidelines to regulate the activities of lobbyist and other political action groups who operate, formally or informally, buying the votes of legislators for their causes in the legislature.

\section{Money Politics and Vote-Buying - The Bane of Good Governance}

Good governance is based on the tenets and practice of democracy. A government that enjoys the trust and support of the majority of the people must be a legitimate one. Legitimacy engenders trust and support of the people to government policies and reform agenda. But money politics and vote-buying erode this very important attribute of democratic government. This is because, it is the conviction among the people that those who rule do so, on the basis of popular 
consent, freely expressed, is the tonic required to make the people make material sacrifices that reform agenda, social, political or economic inevitably demand. The truth is that, without legitimacy, there is no trust, and without trust there can be no genuine political support. It logically follows that without strong support of government policies by majority of the people no reform programme, including electoral reform programme can be successfully carried through and ultimately sustained But with the diabolical role that money played in the 2007 elections, the past civilian regime of Musa Yar'Adua and later Dr. Goodluck Jonathan because President Yar'Adua died on 5th May, 2010 and the then Vice President Dr. Goodluck Jonathan took over. The President cannot be said to enjoy a robust legitimacy among the majority of the people. On the 2007 elections and its legitimacy status, Asobie has this to say:

The set of elections conducted in April 2007 by the Independent National Electoral Commission (INEC), which purportedly produced legislators at both the state and national levels and Governors/Deputy Governors and President/Vice respectively, has created problem of political legitimacy. That problem is yet to be addressed. From the look of things, the electoral tribunals cannot resolve it. It is also unlikely that the ruling class in Nigeria will be minded to find a lasting solution to it. It is the Nigerian people in their non-governmental capacities that seem to have the solution to this political underdevelopment (Asobie, 2007).

Again, spending money beyond what is ordinarily required to defray legitimate campaign expenses by directly or indirectly bribing voters is definitely an electoral malpractice and the favourable electoral results emanating from that would not represent the true wishes of voters i.e. their actual political preference minus the intervention of money.

Also according to Milbrath (1965:24), "people of integrity and those who genuinely want to serve the people but have no money to buy votes may lose out in the electoral contest, while bad candidates with abundant financial resources or those with corrupt tendencies may get elected." When this happens, the immoral and condemnable use of money to buy votes is then celebrated to high heavens, as a good and effective weapon, in electoral battles by successful contestants.

Money Politics and vote-buying has also made election results to have little or nothing to do with the performance in office of politicians. Precisely because performance is not a critical factor in electoral outcome, the incentive to perform is very weak. And because vote-buying is very effective in achieving electoral victory the resort to it is very high. Consequently, elected public office holders who spent huge sums of money to secure victory at the polls would usually have a greater propensity to pursue their private business and financial interest and sometimes those of their corporate sponsors or mentors and financiers, euphemistically referred to in Nigeria as political god-fathers. In this situation, public interest takes the back seat in the calculation, thus degrading the responsibilities of the elected officials to the people. It is for this reason that the Nigeria National Orientation Agency, a public enlightenment body sponsored a radio and television jingle during political campaigns and rallies by which it warned the electorate to be wary of politicians who want to buy their votes because according to the jingle, anyone who uses "wuru-wuru" (crooked, illicit means) to get elected could certainly render "wuru-wuru" service to the people (Davies, op cit)

Another negative impact of money politics and vote-buying on good governance is that the winner in the elections when he occupies a public office that gives him access to public fund becomes more prone to corruption. For instance, if he is a legislator, he becomes more prone to receiving gratifications to promote and support the private interest of his sponsors. There is now a popular feeling, indeed thinking, among a coterie of Nigerian politicians, that political contest is a high risk investment opportunity. The higher the risk the greater the returns. This type of thinking has been corroborated by a former president of the Nigerian Senate when he affirmed in an interview that because votes are not free, politicians considered electoral contest for seats in the National Assembly as an investment and that many of them invest their fortunes, incurred debts and even sold their houses to contest and get elected (See Sunday Punch June, 5, 2005).

The unequivocal message that was being sent by the former president of senate is that if huge sums of money have been invested to contest election then it is inevitable for the investor to strive to recover his money or part of it through different ways.

It therefore logically follows that:

If the investor with the political investments motives wins and is eventually entrusted with power, it is quite logical for people to assume that the pay back is likely to come from public funds (The Guardian Editorial, July 19, 2006).

This kind of unwholesome practice constitutes a serious blemish on public policy and legislative process and consequently brings the highest indignity to the democratic process. 


\title{
6. The Way Forward
}

It is quite doubtful that money politics and vote-buying can be totally eradiated in Nigeria. However, there should be at least some mechanisms by which its negative consequences on good governance can be minimized. For instance, there is also money politics in the United States of America, even when legal limits are fixed in the solicitation, acceptance and disbursement of funds for political campaigns, but such limit has been honoured more in breach than in observance, and American politics has been very much oiled by money from "Fat cat contributions" (Rodee et al, 1976), yet the American government is much more effective in service delivery to the people, than the Nigerian government.

Consequently, it is of primary importance to first and foremost call on all stakeholders in the Nigerian project for attitudinal changes so as to have positive perception of politics. This is because a system of free and fair election is not guaranteed by officially sanctioned legal instrument alone. As Alabi correctly points out:

For example, while stiffer punishment for rigging may be a panacea, such can have meaning only if the enabling legal/judicial system is such that justice is assured at all times. This requires the cooperation and alertness of all the stakeholders- the government, the electoral commission, the political parties, the candidates, the electorate, the civil society and the press each of which must cultivate the right attitudes to make democracy work by ensuring that the game of politics is played according to the rules (Alabi, 2007).

This calls for the right attitudes towards politics essentially questions our democratic credentials as a people. The important issue here is the attitudes and perceptions of the individuals toward election in particular and politics in general. As Ovie-Whiskey rightly notes in respect of the electoral Act, 1982, the problem is not the law as such, but the society, insisting that:

\begin{abstract}
If the individual can have self examination and determine to be honest at elections come what may, there will be free and fair elections. What we need is a deep sense of patriotism and a devoted sense of selfless to the acquisition of wealth by unjust means and refuse to be bought at election time or to commit any electoral offence or other kinds of evils during elections and if we refuse to make ourselves marketable commodities, the elections will be free and fair. Further if we behave like descent persons and law abiding in the absence of uninformed police officers or soldiers, the elections will be free and fair (Ovie-Whisky, cited in Alabi 2007).
\end{abstract}

There is the need for some ethical codes to be enacted for all elected officials to prohibit them from exhibiting stupendous wealth which gives negative signal to the people that election to public office gives one the rare opportunity to amass wealth. This type of signal will of course, unnecessarily raise the stake, push the candidates in elections to see the contest as akin to fight to finish affair, and consequently heat up the polity. On the side of the people, they should shun those politicians displaying ill-gotten wealth knowing fully well that the money belongs to them, but being frequently siphoned by the opportuned politicians. They should show self respect for themselves and hold high their dignity by ignoring and showing disrespect to incompetent but wealthy office holders.

More transparent and effective screening methods must be developed by the political parties and the electoral body, to ensure the exclusion of politicians with overt or convert tendency to corrupt the electoral process and the electorate. There is also the need for political education of the electorate to be more discerning in their electoral choices, and minimize the pressures put on their elected representatives for financial and material rewards for voting.

Again, political parties should refrain from projecting the financial profile of the wealthy candidates and their financial importance to the parties. This is because such candidates have the tendency to want to live up to the image so created by injecting more money into the campaign than is morally justified.

Additionally, party officials should be trained on how to manage electioneering campaigns in which candidates have a well thought out manifestoes. Unlike in the second republic when major political parties clearly articulated their cardinal programmes, the case is not so in the fourth republic where voters are as confused as the politicians.

The mass media has a role to play in sensitizing voters to know their primary responsibilities in electing credible candidates. For example, where the media is celebrating money-bags, who are using their wealth to subvert the democratic process and good governance, the phenomenon on money politics and vote-buying will continue to thrive in the Nigerian political scene.

Finally and much more importantly, the Nigerian economy must be improved upon to empower the people economically. This is because where poverty is reduced to the barest minimum; the electorates can then make independent electoral decisions in voting for credible politicians rather than incompetent but money spending politicians. 


\section{Conclusion}

We have examined the concepts of money politics and vote-buying and their negative impacts on good governance. It is revealed from the analysis that good governance can thrive only when based on the tenets and practice of democracy, which is the best known form of government for now.

The importance of money to run elections in terms of campaign, printing of party manifestoes, emblems and other services is well recognized, but the excessive use of money with the objective of purchasing votes is counterproductive to good governance. This is because once excessive use of money is employed to influence the outcome of elections; the election becomes synonymous with the gentle art of 'getting votes from the poor and campaign funds from the rich by promising to protect one from the other (Sohner, 1973).

The analysis also revealed that any polity where voters are not completely or as much as possible insulated from outside pressures, most especially money, they cannot choose freely. As Andreas Schedler puts it, "if power and money determines electoral choices, constitutional guarantees of democratic freedom and equality turn into dead letters" (Adreas cited in Ojo, 2006). The situation such as this injures good governance. However, the implementation of the policy options as suggested in the way forward of this paper, can help to minimize the negative impact of money politics and vote-buying on good governance in Nigeria.

\section{Refrences}

Alabi, M.O. (2008) "The Electoral Act 2006 and the Conduct of 2007 Election in Nigeria" in H.A. Saliu et al (editors) Nigeria Beyond 2007: Issues, Perspectives and Challenges: Faculty of Business and Social Sciences, University of llorin, llorin.

Asobie, H.A. (2007) "The Answer lies within us" A Presidential Address by Professor H. Asis Asobie at the 26 $6^{\text {th }}$ Annual Conference of the Nigerian Political Science Association (NPSA) held in Bayero University, Kano.

Bara W. (2007) "How Partisan Poll Watching is Transformed into Indirect Vote Buying" Chapel Net: (Christian Action for Peaceful and Meaningful Elections; chapelout/Weng/btml.

Callahan W.A. (2000) Poll Watching, Elections and Civil Society in South East Asia Burlington VT,Ashgate.

Davies, A.E. (2006)"Money And Politics in the Nigeria Electoral Process: A Memo of Department of Political Science, University of Ilorin - llorin.

Dahl, R.A. (1971)"What Makes Democracy Endures Journal of Democracy Vol 1 and No. 1.

Dudley, B. (1982) An Introduction to Nigerian Government And Politics: The McMillan Press, London and Basing Stoke.

Fayemiwo, G. (2008)"Tribunal Confirms Oyinlola Victory at the Poll, Daily Sun Wednesday 16, Lagos.

Fredric C. S. and Andreas, S (2005) What is Vote Buying, The Limit of Market Model being a text of Paper delivered at the conference of 'Poverty' Democracy and Clientism: The Political Economy of Vote Buying' Department of Political Science Stanford University Bellagion Center, Rockefeller Foundation.

The Guardian Newspaper (2008) Tribunal Victories, an Exercise in Futility after all? Sunday May 31st.

Milbrath, L.W. (1965) Political Participation, Chicago, Rand Mc Nally College Publishing Company.

Nwosu, N.I. (1996) "The Nigerian Presidential Election of 1993" Indian Journal of Politics. Vol xxx Nos 1-2.

The News Magazine, July 6 2008, Lagos Nigeria.

Obasanjo O. (2005) Political Party Finance Handbook Independent Electoral Commission (INEC) Abuja.

Ojo, E.O. 'Vote-Buying in Nigeria' Money Politics and Corruption in Nigeria: UK Department for International Development (DFLD) "Nigeria Election Support 2007 Programme.

Punch Newspaper Saturday 5, 2005, Lagos.

Rodee, C.L. et-al (1976) Introduction to Political Science. London Megraw - Hill.

Walecki, M (2006) "Political Money and Corruption" Money Politics and Corruption in Nigeria UK Department (DFLD) under IFES Nigeria Election Support Programmes.

Wright, J.R. (1985): Pacs Contribution and Roll Calls. An Organization Perspective. The American Political Science Review Vol. 79 . No. 2.

Saliu H.A. and Lipade, A. (2008)"Constraint of Democracy in Nigeria" In Perspectives on Nation-Building and Development in Nigeria Political and Legal Issues H.A. Saliu et-al (Editors) Lagos, concept Publications Limited.

Sohner, C.P. (1973) The People's Power American Government and Politics Today, Illinois Scott Foresman and Company.

Suberu, R.T. (2001)"Can Nigeria's New Democracy Survive" Current History. 